\title{
POTENSI LAHAN UNTUK KOLAM IKAN DI KABUPATEN CIANJUR BERDASARKAN ANALISIS KESESUAIAN LAHAN MULTI KRITERIA
}

\section{Land Potency for Freshwater Fishpond in Cianjur Regency Based on Multi Criteria Land Evaluation}

\author{
Wuri Cahyaningrum ${ }^{1}{ }^{\star}$, Widiatmaka2), dan Kadarwan Soewardi ${ }^{3)}$ \\ 1) Alumni Program Studi Ilmu Perencanaan Wilayah, Sekolah Pascasarjana IPB, Jl. Raya Darmaga, Gedung Andi \\ Hakim Nasoetion Kampus IPB Darmaga Bogor 16680 \\ 2) Departemen Ilmu Tanah dan Sumberdaya Lahan, Fakultas Pertanian IPB, J1. Meranti Kampus IPB Darmaga \\ Bogor 16680 \\ 3) Departemen Manajemen Sumberdaya Perairan, Fakultas Perikanan dan Ilmu Kelautan IPB, J1. Agatis Kampus
} IPB Darmaga Bogor 16680

\begin{abstract}
Cianjur Regency is one of the potential areas for developing aquaculture. The largest part of total fish production comes from the floating net cages ("Keramba Jaring Apung"-KJA) Cirata Dam. Recently, the quality of the Cirata Dam has been and being degraded. Therefore, freshwater fishpond can become an alternative development. This study was aimed to identify suitable sites for freshwater ponds. Land suitability was analyzed using Geographic Information System (GIS) and Multi-criteria Evaluation (MCE) methods. The analysis result shows that the suitable land for freshwater ponds was 86,511 ha or $23.89 \%$ of the total region. Of such suitable land, the available land for freshwater ponds was 74,062 ha (20.46\%), while that not available was 12,449 ha (3.44\%). The resuts indicate that freshwater fishpond development is still possible to be done in Cianjur regency.
\end{abstract}

Keywords: Freshwater fishpond, land suitability, MCE, SIG

\begin{abstract}
ABSTRAK
Kabupaten Cianjur merupakan salah satu wilayah yang potensial untuk pengembangan budidaya ikan air tawar. Sampai saat ini, proporsi terbesar dari total produksi ikan berasal dari Keramba Jaring Apung (KJA) Waduk Cirata. Waduk Cirata saat ini sudah dan sedang mengalami penurunan kualitas sehingga mengurangi produksi ikan Kabupaten Cianjur. Oleh karena itu, diperlukan alternatif cara pemeliharaan ikan selain KJA. Salah satunya adalah kolam. Informasi mengenai wilayah yang berpotensi untuk lokasi budidaya ikan merupakan faktor penting dalam pengembangan perikanan. Penelitian ini bertujuan untuk memetakan tingkat kesesuaian lahan untuk kolam. Penentuan kesesuaian lahan dilakukan dengan aplikasi Sistem Informasi Geografis (SIG) dan Evaluasi Multi-kriteria (Multi Criteria Evaluation, MCE). Hasil analisis kesesuaian lahan menunjukkan lokasi yang sesuai untuk kolam seluas 86,511 ha (23.9\% dari total luas wilayah). Hasil analisis terhadap lahan yang sesuai, lokasi yang tersedia seluas 74,062 ha (20.5\%) dan yang tidak tersedia seluas 12,449 ha (3.44\%). Hasil penelitian menunjukkan bahwa pengembangan lahan untuk kolam masih mungkin dilakukan di Kabupaten Cianjur.
\end{abstract}

Kata kunci: Kolam, kesesuaian lahan, MCE, SIG

\section{PENDAHULUAN}

Melimpahnya sumberdaya air memungkinkan perikanan menjadi salah satu sub-sektor yang berpotensi untuk dikembangkan. Produk Domestik Bruto (PDB) subsektor perikanan memang masih relatif kecil kontribusinya, namun menunjukkan kecenderungan yang meningkat. Berdasarkan data Kementerian Kelautan dan Perikanan (KKP), PDB sub-sektor perikanan pada tahun 2011 mengalami kenaikan tertinggi pada kelompok pertanian, yakni mencapai 14.23\% (KKP, 2013).

Kondisi sumberdaya alam berupa iklim, lahan dan air di Kabupaten Cianjur sangat mendukung kegiatan budidaya ikan air tawar. Kegiatan perikanan di Kabupaten Cianjur didominasi oleh perikanan budidaya. Produksi perikanan tahun 2011 mencapai $81,010.84$ ton, terdiri atas perikanan budidaya sebesar 80,900.54 ton (99.9\%) dan perikanan tangkap sebesar 110.30 ton (0.14\%) (BPS, 2012).

Sampai saat ini, produksi ikan di Kabupaten Cianjur masih mengandalkan hasil dari Keramba Jaring Apung (KJA) Waduk Cirata. Waduk Cirata saat ini sudah dan sedang mengalami penurunan kualitas akibat pesatnya pertumbuhan jaring apung yang beroperasi. Hasil penelitian menunjukkan bahwa pengelolaan dan pemanfaatan sumberdaya perikanan di Waduk Cirata sudah melebihi daya dukung lingkungan (Tjahjo dan Suman, 2009) dan mengalami pencemaran berat (Widiyati dan Bengen, 2012). Oleh karena itu, perlu dikembangkan alternatif cara pemeliharaan ikan selain KJA. Berdasarkan 
data hasil produksi ikan, alternatif pengembangan budidaya ikan dapat diarahkan kepada pemeliharaan ikan air tawar di kolam. Produksi ikan di kolam pada tahun 2011 menempati urutan kedua setelah KJA, mencapai 29,847.00 ton (BPS, 2012).

Informasi mengenai wilayah yang berpotensi untuk budidaya merupakan faktor penting dalam pengembangan perikanan. Informasi dan data potensi lahan akan memberikan panduan dalam memilih lokasi yang sesuai untuk kolam. Pemilihan lokasi merupakan kegiatan untuk memutuskan penggunaan yang rasional dari sebuah lahan (Hossain dan Das, 2010). Rasional dalam penggunaan lahan berarti menempatkan sebidang lahan sesuai dengan potensinya. Lokasi yang sesuai untuk pengembangan budidaya akan meminimalkan dampak terhadap lingkungan sekitar dan meningkatkan perekonomian masyarakat (GESAMP dalam Radiarta et al., 2010) serta mengurangi konflik penggunaan lahan dan air (Hossain et al., 2009). Selain itu, pemilihan lokasi merupakan bentuk kontrol dan pengelolaan dalam pengembangan perikanan (Radiarta et al., 2008)

Salah satu metode yang dapat digunakan untuk pemilihan lokasi budidaya ikan adalah melalui Sistem Informasi Geografis (Nath et al., 2000) dan analisis multikriteria (Malczewski, 1999). Penelitian ini bertujuan untuk memetakan tingkat kesesuaian lahan untuk kolam ikan di Kabupaten Cianjur. Hasil penelitian diharapkan dapat menjadi dasar bagi perencanaan lebih lanjut untuk pengembangan perikanan di Kabupaten Cianjur.

\section{BAHAN DAN METODE}

Penelitian dilaksanakan di Kabupaten Cianjur, Provinsi Jawa Barat. Kabupaten Cianjur memiliki luas 361,944 ha dengan 32 kecamatan. Kabupaten Cianjur dibedakan dalam tiga bagian wilayah yaitu wilayah Cianjur bagian utara, bagian tengah dan bagian selatan. Wilayah Cianjur bagian utara merupakan daerah pegunungan dan dataran yang saat ini banyak digunakan untuk areal perkebunan dan persawahan. Wilayah Cianjur bagian tengah merupakan daerah yang berbukit-bukit dengan struktur tanah yang labil sehingga sering terjadi longsor. Wilayah Cianjur bagian selatan merupakan daerah dataran rendah dengan banyak bukit yang diselingi oleh pegunungan yang melebar sampai ke daerah pantai Samudera Indonesia. Seperti halnya daerah Cianjur bagian tengah, bagian selatanpun tanahnya labil. Luas wilayah
Cianjur bagian selatan paling luas $(40.8 \%$ dari total luas wilayah) dibandingkan dengan bagian wilayah lainnya.

Data yang digunakan dalam penelitian ini meliputi data primer dan data sekunder. Data primer diperoleh melalui wawancara terhadap lima orang responden. Data sekunder yang digunakan meliputi Peta Rupa Bumi Indonesia (RBI) (Bappeda, 2011), peta-peta tematik, laporan dan literatur. Peta tematik yang digunakan adalah Peta Penggunaan Lahan tahun 2011, Peta Rencana Tata Ruang Wilayah (RTRW) Kabupaten Cianjur, Peta Kelerengan, Peta Curah Hujan, Peta Sungai, Peta Jaringan Jalan (Bappeda, 2011) dan Peta Satuan Tanah dan Lahan (Puslittanak, 2011).

\section{Analisis Kesesuaian Lahan}

Kesesuaian lahan untuk kolam dianalisis secara spasial menggunakan Sistem Informasi Geografis (SIG) dengan metode Multi Criteria Evaluation (MCE). MCE merupakan suatu proses melalui analisis terstruktur menggunakan Analytical Hierarchy Process (AHP) untuk menentukan tujuan dan menetapkan kriteria. Penelitian ini menggunakan dua kriteria, yaitu kriteria ekologis dan kriteria sosial-ekonomi. Kriteria ekologis yang digunakan terdiri dari empat faktor yaitu kelerengan, tekstur tanah, curah hujan dan jarak dari sungai. Kriteria sosial-ekonomi yang digunakan terdiri dari tiga faktor yaitu jarak dari jalan, jarak dari permukiman dan penggunaan lahan saat ini. Selanjutnya masing-masing faktor terdiri dari empat sub-faktor. Dalam penelitian ini, kesesuaian lahan untuk kolam diklasifikasikan dalam empat kelas (Tabel 1).

Metode MCE diawali dengan pembobotan kriteria, faktor dan sub-faktor menggunakan AHP (Saaty, 1994). Setelah seluruh bobot ditentukan, langkah selanjutnya adalah melakukan analisis spasial menggunakan teknik Weighted Linear Combination (WLC) (Malczewski, 1999). Bobot setiap sub-faktor hasil analisis AHP dimasukkan ke dalam peta setiap faktor. Bobot sub-faktor berperan sebagai derajat kesesuaian yang akan digunakan dalam persamaan WLC. Persamaan WLC secara umum adalah:

$$
\mathrm{WLC}=\left(\sum_{i=1}^{n} \mathrm{Xij} \times \mathrm{Wij}\right) \times \mathrm{Cj}
$$

dimana: WLC : Weighted Linear Combination; Xij: Bobot sub faktor ke-j di lokasi ke-i; Wij : Bobot faktor ke-j di lokasi ke-i; $\mathrm{n}$ : Jumlah faktor; $\mathrm{Cj}$ : kendala

Tabel 1. Kriteria kesesuaian lahan untuk kolam

\begin{tabular}{|c|c|c|c|c|c|}
\hline \multirow{2}{*}{ Kriteria } & \multirow{2}{*}{ Faktor } & \multicolumn{4}{|c|}{ Kelas Kesesuaian Lahan } \\
\hline & & 1 & 2 & 3 & 4 \\
\hline \multirow[t]{4}{*}{ Ekologis } & Kelerengan $(\%)^{\mathrm{a}}$ & $0-3$ & $>3-8$ & $>3-8$ & $>8$ \\
\hline & Tekstur tanah $^{\mathrm{b}}$ & Liat/liat berpasir & Lempung & Lempung berpasir & Pasir \\
\hline & Curah hujan $\left(\mathrm{mm} \mathrm{thn}^{-1}\right)^{\mathrm{b}}$ & $<1,000$ & $>1,000-2,000$ & $>2,000-2,500$ & $>2,500$ \\
\hline & Jarak dari sungai $(m)^{\mathrm{c}}$ & $<500$ & $>500-1,000$ & $>1,000-1,500$ & $>1,500$ \\
\hline \multirow{3}{*}{$\begin{array}{l}\text { Sosial- } \\
\text { ekonomi }\end{array}$} & Jarak dari jalan $(\mathrm{m})^{\mathrm{c}}$ & $<500$ & $>500-1,000$ & $>1,000-1,500$ & $>1,500$ \\
\hline & Jarak dari permukiman $(\mathrm{m})^{\mathrm{c}}$ & $<400$ & $>400-800$ & $>800-1,200$ & $>1,200$ \\
\hline & Penggunaan lahan $^{\mathrm{d}}$ & Kolam & Ladang & Kebun & Semak belukar \\
\hline
\end{tabular}

Sumber: ${ }^{\mathrm{a}}$ Hardjowigeno dan Widiatmaka (2007) dimodifikasi; ${ }^{\mathrm{b}}$ Poernomo (1989); ${ }^{\mathrm{c}}$ Radiarta et al. (2012) dimodifikasi; ${ }^{\mathrm{d}}$ Hardjowigeno dan Widiatmaka (2007) dan Radiarta et al. (2012).

Analisis kesesuaian lahan dilakukan secara bertahap, yaitu kesesuaian lahan berdasarkan kriteria ekologis, sosial-ekonomi dan kesesuaian untuk kolam secara keseluruhan. Kesesuaian lahan berdasar kriteria ekologis diperoleh dengan fungsi overlay yaitu intersect pada empat faktor (kelerengan, tekstur tanah, curah hujan 
dan jarak dari sungai), sedangkan berdasar kriteria sosialekonomi diperoleh melalui overlay tiga faktor (jarak dari jalan, jarak dari permukiman dan penggunaan lahan saat ini). Analisis kesesuaian lahan secara keseluruhan dilakukan dengan intersect peta kesesuaian lahan berdasar kriteria ekologis dan berdasar kriteria sosial-ekonomi. Lahan yang berfungsi sebagai kendala (constraint) tidak dimasukkan dalam fungsi overlay. Kendala berasal dari faktor penggunaan lahan saat ini, yaitu perkebunan, hutan, permukiman, bangunan, sawah dan waduk.

Tahap selanjutnya adalah menambahkan field dan melakukan perhitungan dengan menggunakan field calculator. Terhadap hasil perhitungan dengan menggunakan persamaan di atas, dilakukan query yaitu SQL (Select By Attributes) untuk penentuan kelas. Penentuan kelas mengacu kepada bobot sub-faktor yang telah diperoleh. Review terhadap batas selang kelas S1 (sangat sesuai), S2 (sesuai) dan S3 (sesuai marjinal) dilakukan dengan melakukan pengamatan di lapang. Produksi ikan di lapang ditanyakan kepada pembudidaya, ditentukan koordinatnya dan di-match-kan lokasinya pada peta. Setiap kelas ditetapkan sebanyak tiga pembudidaya. Pembudidaya yang dipilih diasumsikan mempunyai pola budidaya yang sama untuk mengurangi bias terhadap produksi ikan yang dihasilkan. Untuk perencanaan penggunaan lahan, selain kesesuaian lahan, perlu diketahui ketersediaan lahannya. Untuk itu, dilakukan tumpang susun (overlay) peta kesesuaian lahan dengan peta RTRW sehingga diperoleh lahan yang sesuai dan tersedia untuk kolam.

\section{HASIL DAN PEMBAHASAN}

\section{Hasil AHP untuk Penentuan Bobot Kriteria, Faktor dan Sub-Faktor}

Nilai bobot kriteria dan faktor disajikan pada Tabel 2. Hasil analisis AHP untuk penentuan bobot kriteria menunjukkan bahwa kriteria sosial-ekonomi mempunyai bobot lebih besar daripada kriteria ekologis. Radiarta et al. (2008) menyatakan bahwa kriteria ini dapat meningkatkan produktivitas dan kualitas produk perikanan, karena berkaitan dengan aksebilitas yang lebih mudah/terjangkau.

Analisis faktor yang termasuk kriteria ekologis menunjukkan bahwa kelerengan mempunyai bobot tertinggi (0.3507). Kolam cenderung memerlukan area dengan bentuk lahan yang datar. Pada daerah yang lebih curam akan diperlukan biaya pembuatan konstruksi kolam yang lebih besar. Bobot paling kecil ditunjukkan oleh tekstur tanah. Tanah berperan untuk menahan air selama proses budidaya ikan. Namun, teknologi yang dapat memanipulasi tekstur tanah yang kurang cocok untuk budidaya ikan sudah banyak diterapkan oleh pembudidaya, sehingga faktor ini memperoleh bobot yang kecil. Analisis terhadap faktor dalam kriteria sosial-ekonomi menunjukkan bahwa faktor penggunaan lahan saat ini memperoleh bobot paling tinggi (0.3872). Penggunaan lahan saat ini menggambarkan kesesuaian lahan dan peruntukan lahan (aspek legal).
Tabel 2. Nilai bobot kriteria dan faktor berdasarkan AHP

\begin{tabular}{|c|c|c|c|c|c|}
\hline Kriteria & Faktor & Bobot & Kriteria & Faktor & Bobot \\
\hline \multirow{5}{*}{$\begin{array}{l}\text { Ekologis } \\
(0.4500)\end{array}$} & Kelerengan & 0.3507 & \multirow{5}{*}{$\begin{array}{l}\text { Sosial- } \\
\text { ekonomi } \\
(0.5500)\end{array}$} & Penggunaan lahan & 0.3872 \\
\hline & $\begin{array}{l}\text { Jarak dari } \\
\text { sungai }\end{array}$ & 0.2797 & & Jarak dari jalan & 0.3265 \\
\hline & $\begin{array}{l}\text { Curah } \\
\text { hujan }\end{array}$ & 0.2083 & & \multirow{2}{*}{$\begin{array}{l}\text { Jarak dari } \\
\text { permukiman }\end{array}$} & \multirow{2}{*}{0.2863} \\
\hline & $\begin{array}{l}\text { Tekstur } \\
\text { tanah }\end{array}$ & 0.1613 & & & \\
\hline & Jumlah & 1.0000 & & Jumlah & 1.0000 \\
\hline
\end{tabular}

Hasil analisis WLC setiap jenis kesesuaian lahan berdasarkan bobot faktor adalah:

(a) Kesesuaian lahan berdasarkan kriteria ekologis $\left(\mathrm{WLC}_{1}\right)$

$W L C_{1}=(0.3507 *$ kelerengan $)+(0.2797 *$ jarak dari sungai $)+(0.2083 *$ curah hujan $)+(0.1613 *$ tekstur tanah)

(b) Kesesuaian lahan berdasarkan kriteria sosialekonomi $\left(\mathrm{WLC}_{2}\right)$

$W L C_{2}=(0.3872 *$ penggunaan lahan $)+(0.3265 *$ jarak dari jalan $)+(0.2863 *$ jarak dari permukiman $)$

(c) Kesesuaian lahan secara keseluruhan $\left(\mathrm{WLC}_{3}\right)$

$W L C_{3}=\left(0.4500 * W L C_{1}\right)+\left(0.5500 * W L C_{2}\right)$

\section{Kendala (Constraint)}

Kendala menunjukkan pembatas dalam pemilihan alternatif untuk penentuan lokasi lahan sesuai (Radiarta et al., 2008). Karena itu, lahan yang ditetapkan sebagai kendala dikeluarkan dari analisis kesesuaian lahan. Kendala dalam penelitian ini berasal dari beberapa penggunaan lahan yaitu hutan, perkebunan, permukiman, bangunan, sawah dan waduk. Waduk dikeluarkan dari areal potensial untuk kolam karena berkaitan dengan tujuan penelitian yaitu mendapatkan lahan yang sesuai untuk kolam sebagai alternatif budidaya ikan selain KJA Waduk Cirata. Sawah ditetapkan sebagai pembatas karena potensinya akan dianalisis tersendiri untuk kesesuaian lahan minapadi. Pemanfaatan lahan sebagai pembatas banyak ditemukan pada penelitian mengenai kesesuaian lahan untuk perikanan seperti yang diterapkan oleh Hossain et al. (2009) dan Radiarta et al. (2012). Lahan yang ditetapkan sebagai kendala seluas 165,402 ha $(45.7 \%$ dari total luas wilayah).

\section{Kesesuaian Berdasarkan Kriteria Ekologis dan Sosial- Ekonomi}

Analisis WLC menggunakan nilai bobot sesuai hasil analisis AHP menghasilkan luas kesesuaian lahan berdasar kriteria ekologis dan sosial-ekonomi beserta derajat kesesuaiannya. Derajat kesesuaian untuk kriteria ekologis berkisar antara 0.0000 sampai dengan 0.3636 , sedangkan untuk kriteria sosial-ekonomi berkisar antara 0.0000 sampai dengan 0.3712 (Tabel 3). Semakin mendekati nilai 0.3636 dan 0.3712 berarti lahan semakin sesuai untuk kolam. 
Tabel 3. Derajat kesesuaian berdasar kriteria ekologis dan sosial-ekonomi

\begin{tabular}{ccc}
\hline \multirow{2}{*}{$\begin{array}{c}\text { Kelas Kesesuaian } \\
\text { Lahan } \\
\text { untuk kolam }\end{array}$} & \multicolumn{2}{c}{ Derajat Kesesuaian Lahan untuk Kolam } \\
\cline { 2 - 3 } & Ekologis & Sosial-Ekonomi \\
S1 & $0.3198-0.3636$ & $0.3161-0.3712$ \\
S2 & $0.2667-0.3197$ & $0.2141-0.3160$ \\
S3 & $0.1604-0.2666$ & $0.1277-0.2140$ \\
N & $0.0000-0.1603$ & $0.0000-0.1276$ \\
\hline
\end{tabular}

Analisis spasial terhadap tujuh faktor yang terbagi menjadi dua kriteria bertujuan untuk memperoleh hasil analisis kesesuaian lahan yang menyeluruh (Gambar 1). Hasil analisis berdasarkan kedua kriteria menunjukkan bahwa potensi lahan untuk kolam secara ekologis lebih rendah dibandingkan secara sosial-ekonomi (Tabel 4).

Tabel 4. Luas lahan sesuai dan tidak sesuai untuk kolam berdasarkan kriteria ekologis dan sosial-ekonomi

\begin{tabular}{ccccc}
\hline \multirow{2}{*}{$\begin{array}{c}\text { Kelas Kesesuaian Lahan } \\
\text { untuk kolam }\end{array}$} & \multicolumn{2}{c}{ Kriteria Ekologis } & \multicolumn{2}{c}{ Kriteria Sosial-Ekonomis } \\
\cline { 2 - 5 } & Luas (ha) & Persentase (\%) & Luas (ha) & Persentase (\%) \\
\hline S1 & 8,703 & 2.40 & 14,772 & 4.08 \\
S2 & 25,039 & 6.92 & 98,025 & 27.08 \\
S3 & 97,992 & 27.08 & 53,279 & 14.72 \\
N & 230,210 & 63.60 & 195,868 & 54.12 \\
\hline Jumlah & $\mathbf{3 6 1 , 9 4 4}$ & $\mathbf{1 0 0 . 0 0}$ & $\mathbf{3 6 1 , 9 4 4}$ & $\mathbf{1 0 0 . 0 0}$ \\
\hline
\end{tabular}

Luas lahan hasil analisis kesesuaian berdasar kriteria ekologis dan sosial-ekonomi dipengaruhi oleh faktor yang membentuknya. Berdasarkan kriteria ekologis, lahan paling luas berada pada kelas S3 karena kondisi wilayah Kabupaten Cianjur sebagian besar berupa perbukitan sampai pegunungan. Berdasarkan kriteria sosial-ekonomi, lahan paling luas berada pada kelas S2 karena adanya pemanfaatan lahan berupa ladang/tegalan.

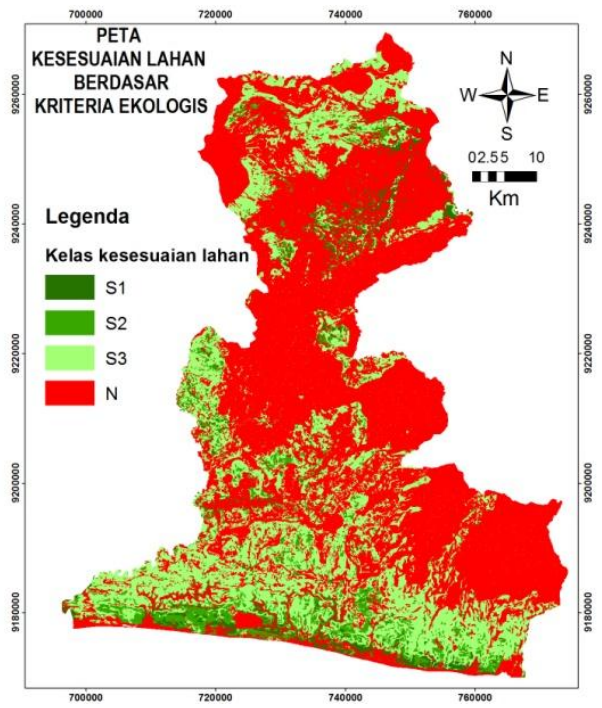

(a) kriteria ekologis

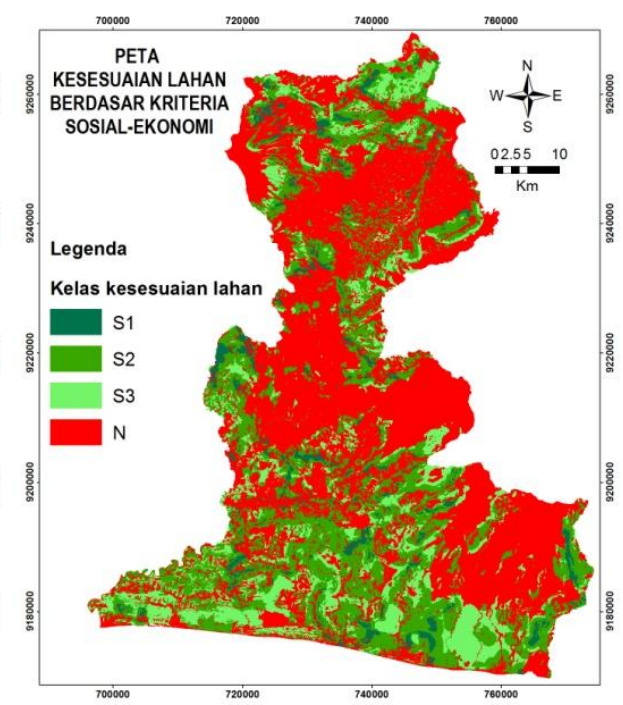

(b) kriteria sosial-ekonomi

Gambar 1. Peta kesesuaian lahan untuk kolam berdasarkan kriteria ekologis (a) dan sosial-ekonomi (b)

\section{Kesesuaian dan Ketersediaan Lahan untuk Kolam}

Hasil analisis kesesuaian dan ketersediaan lahan memberi gambaran bahwa lahan yang sesuai dan tersedia untuk kolam lebih kecil dibandingkan dengan lahan yang tidak sesuai dan tidak tersedia untuk kolam (Gambar 2). Analisis ketersediaan lahan dapat digunakan sebagai arahan pengembangan perikanan karena telah mempertimbangkan pola ruangnya. Kabupaten Cianjur telah menetapkan Peraturan Daerah Kabupaten Cianjur Nomor 17 tahun 2012 Tentang Rencana Tata Ruang Wilayah (RTRW) Kabupaten Cianjur Tahun 2011-2031. RTRW tersebut mengatur penataan ruang. Salah satunya mengatur fungsi kawasan budidaya.
Lahan yang sesuai untuk kolam berdasarkan hasil analisis kesesuaian sebesar 86,511 ha, sedangkan luas lahan yang tersedia untuk kolam sebesar 74,062 ha (Tabel 5). Tentu saja lahan seluas itu barulah potensi lahan untuk pengembangan kolam. Lahan yang tidak tersedia karena telah digunakan untuk kegiatan lain atau tidak sesuai dengan alokasi lahan yang telah ditetapkan dalam RTRW perlu dikeluarkan dari potensi tersebut. Di Kabupaten Cianjur terdapat lima pola ruang dalam RTRW yaitu budidaya kehutanan, budidaya non pertanian, kawasan budidaya, kawasan lindung hutan dan kawasan lindung non hutan. 

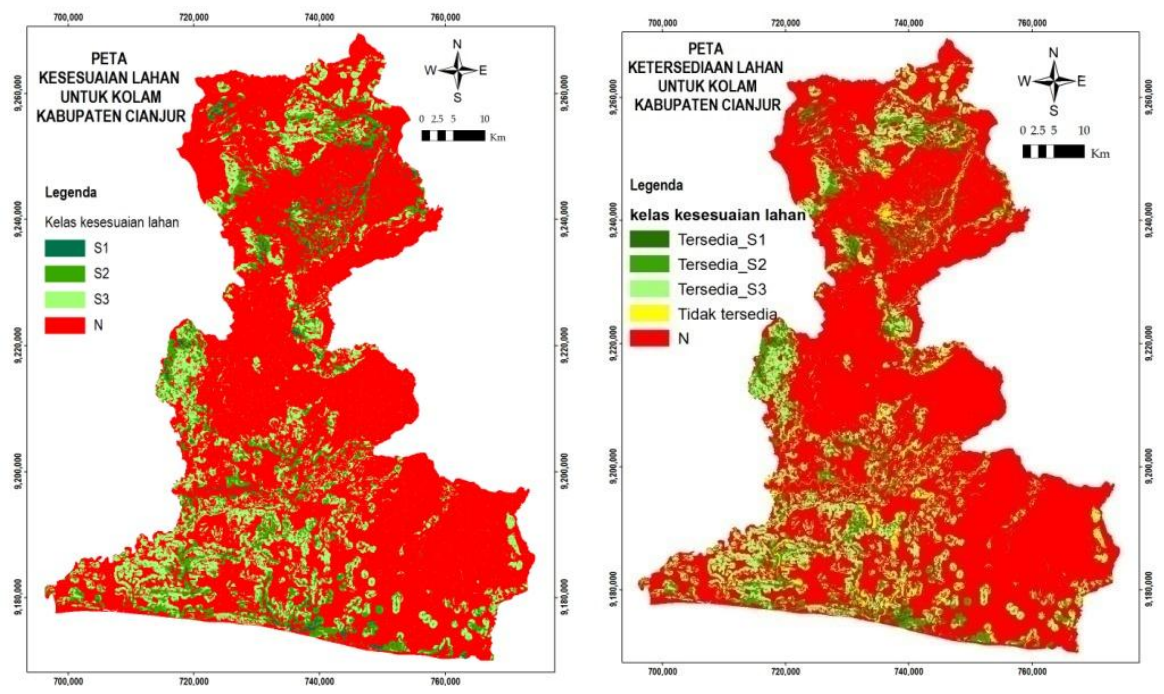

Gambar 2. Peta kesesuaian dan ketersediaan lahan untuk kolam di Kabupaten Cianjur

Tabel 5. Luas kesesuaian dan ketersediaan lahan untuk kolam

\begin{tabular}{|c|c|c|c|c|}
\hline \multirow{2}{*}{ Kelas Kesesuaian Lahan } & \multicolumn{2}{|c|}{ Kesesuaian Lahan untuk Kolam } & \multicolumn{2}{|c|}{ Ketersediaan Lahan untuk Kolam } \\
\hline & Luas (ha) & Persentase (\%) & Luas (ha) & Persentase (\%) \\
\hline S1 & 3,547 & 0.98 & 2,549 & 0.70 \\
\hline S2 & 29,652 & 8.19 & 25,563 & 7.06 \\
\hline S3 & 53,312 & 14.73 & 45,950 & 12.69 \\
\hline Jumlah sesuai/tersedia (a) & 86,511 & 23.89 & 74,062 & 20.46 \\
\hline $\begin{array}{ll}\mathrm{N} & \text { (b) }\end{array}$ & 275,433 & 76.11 & 275,433 & 76.11 \\
\hline Tidak Tersedia $\quad$ (c) & - & - & 12,449 & 3.44 \\
\hline Jumlah $(a+b+c)$ & 361,944 & 100.00 & 361,944 & 100.00 \\
\hline
\end{tabular}

Lahan pada kelas sangat sesuai (S1) didukung oleh kondisi ekologis dan sosial-ekonomi yang sesuai untuk kolam. Lahan pada kelas cukup sesuai (S2) dan sesuai marginal (S3) memiliki pembatas yang dapat mengurangi produksi sehingga mutlak diperlukan input atau teknologi untuk meningkatkan produksi. Hardjowigeno dan Widiatmaka (2011) menyebutkan bahwa lahan dengan kelas S2 memerlukan masukan untuk memperbaiki faktor pembatas, dengan intensitas masukan yang lebih kecil dibandingkan dengan masukan untuk lahan kelas S3, sehingga dapat diatasi oleh petani sendiri.

Secara umum, lahan yang sesuai untuk kolam tersebar di seluruh bagian wilayah Kabupaten Cianjur. Lahan pada kelas S1 dan S2 banyak terdapat di wilayah Cianjur bagian utara dan selatan, dibandingkan dengan wilayah Cianjur bagian tengah. Lahan pada kelas sesuai marginal (S3) banyak terdapat di wilayah Cianjur bagian tengah dan selatan. Wilayah Cianjur bagian utara mempunyai bentuk lahan yang datar dan dekat dengan sungai sebagai sumber air. Selain itu, ketersediaan infrastruktur seperti jaringan jalan di wilayah Cianjur bagian utara lebih baik dibandingkan dengan wilayah lainnya. Wilayah Cianjur bagian tengah sebagian berbentuk lahan yang curam dengan ketersediaan sumber air (sungai) sedikit. Dengan demikian, apabila dilihat dari luas lahan yang sesuai pada kelas S1 dan S2 maka pengembangan kolam dapat diarahkan ke wilayah Cianjur bagian utara dan selatan.

Potensi lahan untuk kolam dapat diketahui dari perbandingan luas lahan hasil analisis kesesuaian dan ketersediaan dengan luas lahan eksistingnya. Seperti telah disebutkan sebelumnya bahwa lahan yang sesuai dan tersedia untuk kolam sebesar 74,062 ha. Apabila luas lahan tersebut dikurangi dengan luas eksisting (1,970 ha) maka potensi lahan yang dapat digunakan untuk kolam seluas 72,092 ha yang tersebar pada semua kelas kesesuaian. Potensi lahan untuk kolam pada kelas S1 seluas 579 ha, lahan kelas S2 seluas 23,593 ha dan lahan kelas S3 seluas 43,980 ha.

Potensi lahan kelas S1 dapat menjadi prioritas utama untuk pengembangan kolam. Pengembangan kolam pada lahan kelas ini akan memberikan keuntungan yang lebih besar karena lahan tidak mempunyai pembatas yang besar atau pembatas yang ada tidak akan berpengaruh nyata terhadap produksi (Hardjowigeno dan Widiatmaka, 2011). Wilayah Cianjur bagian utara memiliki potensi lahan untuk kolam yang paling baik. Selain didukung oleh ketersediaan lahan, wilayah Cianjur bagian utara mempunyai aksesibilitas yang lebih baik dibanding wilayah lainnya. Pengembangan lahan untuk kolam di wilayah ini akan menghadapi ancaman berupa konflik penggunaan lahan karena merupakan pusat aktivitas masyarakat, seperti perekonomian dan pemerintahan.

Selain pada lahan kelas S1, pengembangan kolam dapat dilakukan di kecamatan-kecamatan yang mempunyai lahan kelas S2. Apabila dilihat dari luas lahan yang tersedia pada lahan kelas S2 maka wilayah Cianjur bagian selatan dapat dikembangkan sebagai pendukung pengembangan perikanan. Selama ini, wilayah ini belum menunjukkan produksi perikanan yang tinggi. Oleh karena itu, pengembangan budidaya ikan di kolam dapat mulai diarahkan ke wilayah Cianjur bagian selatan. Akan tetapi, pengembangan pada lahan dengan kelas kesesuaian S2 memerlukan pengelolaan untuk mengatasi faktor pembatas 
sehingga budidaya yang dilakukan tetap memberikan keuntungan bagi pembudidaya.

\section{Pengamatan Lapang}

Pengamatan lapang dilakukan terhadap pembudidaya di Kecamatan Karangtengah, Mande,
Ciranjang, Sukaluyu, Cianjur, Cibeber dan Cikalongkulon (Gambar 3). Pembudidaya yang diamati berasal dari usaha pedederan IV yaitu pemeliharaan benih dari ukuran belo (5 - $8 \mathrm{~cm}$ ) sampai benih ukuran sangkal $(8-12 \mathrm{~cm})$. Ikan yang diamati adalah Ikan Mas dan Nila. Pemilihan kecamatan mengacu pada luas lahan eksisting dan luas lahan sesuai untuk kolam yang cukup besar.

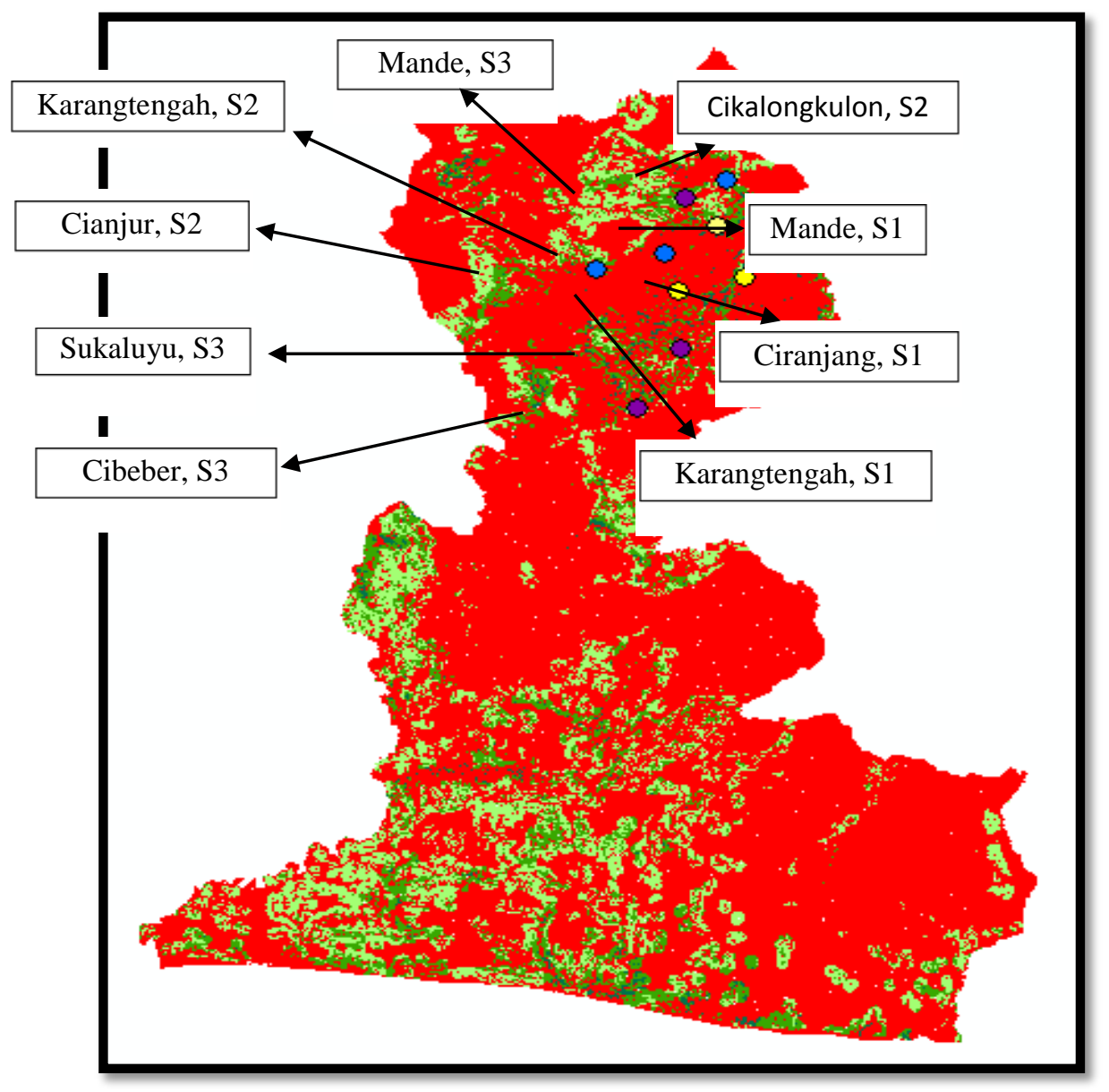

Gambar 3. Titik-titik pengamatan lapang penentuan selang kelas analisis kesesuaian lahan untuk kolam

Hasil pengamatan lapang menunjukkan bahwa selang kelas yang ditentukan berdasarkan bobot sub-faktor sesuai dengan lokasi yang diamati. Produksi pada lahan kelas S1 rata-rata 190,000-200,000 ekor $\mathrm{ha}^{-1} \mathrm{MT}^{-1}$. Produksi pada lahan kelas S2 rata-rata 120,000-160,000 ekor ha ${ }^{-1} \mathrm{MT}^{-1}$, sedangkan pada lahan kelas S3 kurang dari 100,000 ekor ha $^{-1} \mathrm{MT}^{-1}$. Pada lahan-lahan kelas S2 yang diamati mempunyai pembatas berupa jarak dari sungai dan lereng. Adapun lahan-lahan kelas S3 mempunyai pembatas berupa lereng, jarak dari sungai dan jarak dari jalan. Jarak dari sungai yang semakin jauh dapat menyebabkan kualitas air yang sampai di lokasi budidaya menjadi lebih rendah dibandingkan dengan lokasi yang lebih dekat dengan sumber air. Hal ini karena jarak sungai yang semakin jauh dimungkinkan telah mengalami penurunan akibat limbah rumahtangga maupun limbah produksi.

\section{SIMPULAN}

Hasil analisis kesesuaian dan ketersediaan lahan menunjukkan bahwa pengembangan lahan untuk kolam dapat dilakukan di Kabupaten Cianjur. Lahan yang sesuai untuk kolam seluas 86,511 ha $(23.9 \%)$, dengan lahan yang tersedia seluas 74,062 ha $(20.5 \%)$ dan yang tidak tersedia sebesar 12,449 ha $(3.44 \%)$. Berdasarkan wilayahnya, maka pengembangan kolam dapat diarahkan ke wilayah Cianjur bagian utara dan selatan. Wilayah Cianjur bagian utara memiliki potensi lahan untuk kolam yang paling baik karena memiliki luas lahan yang tersedia pada kelas S1 yang paling tinggi. Wilayah ini dapat ditetapkan sebagai prioritas pertama untuk pengembangan kolam. Wilayah Cianjur bagian selatan dapat dikembangkan sebagai pendukung pengembangan perikanan karena memiliki luas lahan yang tersedia pada kelas S2. Wilayah Cianjur bagian tengah memiliki luas lahan yang tinggi pada kelas S3 sehingga kurang menguntungkan untuk pengembangan kolam karena memerlukan masukan yang besar untuk mengatasi faktor pembatas.

\section{UCAPAN TERIMAKASIH}

Ucapan terima kasih disampaikan kepada Pusat Pembinaan dan Pendidikan Pelatihan Perencana Badan Perencanaan Pembangunan Nasional (Pusbindiklatren 
Bappenas) yang telah mendukung pendanaan penelitian ini.

\section{DAFTAR PUSTAKA}

[Bappeda] Badan Perencanaan dan Pembangunan Daerah Kabupaten Cianjur. 2011. Peta Kabupaten Cianjur Tahun 2011. Cianjur.

[BPS] Badan Pusat Statistik Kabupaten Cianjur. 2012. Kabupaten Cianjur dalam Angka. Cianjur.

[FAO] Food and Agriculture Organization. 1976. A Framewok for Land Evaluation. FAO Soils Bull No. 32: 72 pp. Rome.

Hardjowigeno, S. dan Widiatmaka. 2007. Kesesuaian Lahan dan Perencanaan Tataguna Tanah. IPB. Bogor.

Hardjowigeno, S. dan Widiatmaka. 2011. Evaluasi Kesesuaian Lahan dan Perencanaan Tata Guna Lahan. Gadjah Mada University Press. Yogyakarta.

Hossain, M.S., Chowdhury, S.R., Das, N.G., Sharifuzzaman, S.M., and A. Sultana. 2009. Integration of GIS and multicriteria decision analysis for urban aquaculture development in Bangladesh. Landscape and Urban Planning, 90: 119-133.

Hossain, M.S. and Das, N.G. 2010. GIS-based MultiCriteria Evaluation land suitability modelling for Giant Prawn (Macrobrachium Rosenbergii) farming in Companigonj Upazila of Noakhali, Bangladesh. Computer and Electronics in Agriculture. 70: 172-186.

[KKP] Kementerian Kelautan dan Perikanan. 2013. Data Statistik Kelautan dan Perikanan. Jakarta.

Malczewski, J. 1999. GIS and Multicriteria Decision Analysis. John Willey \& Sons, New York. 392 pp.

Nath, S.S., P.B. John, G.R. Lindsay, and J. AguilarManjarrez. 2000. Applications of Geographical
Information System (GIS) for spatial decision support in aquaculture. Aquacultural Engineering, 23: 233-278.

Poernomo, A. 1989. Faktor Lingkungan Dominan pada Budidaya Udang Intensif. Yayasan Obor Indonesia. Jakarta.

[Puslittanak] Pusat Penelitian Tanah dan Agroklimat. 2011. Peta Sumberdaya Tanah Pulau Jawa dan Madura. Bogor.

Radiarta, I.N., S.I. Saitoh, and A. Miyazono. 2008. GISbased Multi-Criteria Evaluation models for identifying suitable sites for Japanese Scallop (Mizuhopecten yessoensis) aquaculture in Funka Bay, Southwestern Hokkaido, Japan. Aquaculture, 284: 127-135.

Radiarta, I.N., A. Sudradjat, dan E Kusnendar. 2010. Analisis spasial potensi kawasan budidaya laut di Propinsi Maluku Utara dengan aplikasi data penginderaan jauh dan Sistem Informasi Geografis. Jurnal Riset Akuakultur, 5: 143 - 153.

Radiarta, I.N, J. Subagja, A. Saputra, dan Erlania. 2012. Pengembangan budidaya Ikan Lele di kawasan minapolitan Kabupaten Bogor, Jawa Barat: Aspek kesesuaian lahan, implementasi produksi dan strategi pengembangan. Jurnal Riset Akuakultur, 7: 307-320.

Saaty, T.L. 1994. Fundamentals of Analytic Hierarchy Process. RWS Publication, Pittsburgh.

Tjahjo, D.W.H. dan A. Suman. 2009. Pengelolaan perikanan Waduk Saguling, Cirata dan Ir. H. Djuanda, Jawa Barat. Jurnal Kebijakan Perikanan Indonesia, 1: 133-120.

Widiyati, A. dan D.G. Bengen. 2012. Kajian aspek keberlanjutan pada pengelolaan perikanan budidaya keramba jaring apung di Waduk Cirata (Jawa Barat). Jurnal Riset Akuakultur, 7: 121. 